\title{
The Texas Consortium to Microfilm Mexican Archival Resources
}

\begin{abstract}
Sixteen Texas libraries, in June 1969, founded the Texas Consortium to Microfilm Mexican Archival Resources in a cooperative effort to preserve Mexican records for research. During its first year, several microfilming projects were inaugurated in Mexico and approximately $\$ 50,000$ was committed. A minimum of $\$ 160,000$ will be budgeted for microfilming projects over a five-year period. Members of the Texas Consortium choose an area of Mexico in which they wish to work, and the Consortium coordinates activities.
\end{abstract}

\begin{abstract}
O NE OF THE MOST potentially significant international cooperative programs of library acquisitions of archival records is the Texas Consortium to Microfilm Mexican Archival Resources. This organization, composed of the Texas State Library and fifteen Texas academic institutions, came into existence a little over one year ago. The ambitious, and probably impossible, goal is to microfilm, in cooperation with Mexican authorities and institutions, all of Mexico's archival resources: national, state, municipal, and ecclesiastical.

There are many reasons for the Texas Consortium: many irreplaceable records in Mexico are in imminent danger of destruction unless they can be recorded on microfilm; many of Mexico's archives are relatively difficult to reach by American scholars; and no one institution, Mexican or Texan, has the resources to undertake such an extensive and expensive project.
\end{abstract}

\section{BACKGROUND}

The idea for a Texas Consortium to microfilm Mexican archival resources tin.

Mr. Kinney is Texas state archivist, Aus- was conceived at a conference held at the State University of New York at Oyster Bay in October 1967.1 This meeting, the International Conference on Mexico on Microfilm was convened by the Office of International Librarianship, Learning Resources and Information Services, International Studies and World Affairs, State University of New York at Oyster Bay. ${ }^{2}$ It was represented by forty-three librarians and Latin American scholars. Texas was represented by five delegates from four institutions. At this Oyster Bay conference, the need for cooperation in microfilming was obvious to all those in attendance. One result of this conference was plans for the formation of a national consortium of about ten institutions, to be called "Mexico on Microfilm," who would agree to cooperate in the microfilming of Mexican archives, beginning in Guadalajara where especially valuable documents are concentrated and where Mexican authorities have offered to cooperate in a microfilming program. One Texas institution, Texas Tech, elected to become a member of this national consortium.

The five Texas representatives at the 
Oyster Bay conference, while favoring a national consortium, felt that in a state where interest in Mexico runs deep, a Texas Consortium should be organized for a long-range project to preserve on film the total archival records of Mexico. The Texas Consortium was not to be competitive with the national consortium or with the work of other groups or individuals. The Texas Consortium supplements and complements other microfilming projects throughout the twenty-nine states, two territories, and the federal district of Mexico. A special committee of SCOLAS (Southwestern Conference on Latin American Studies) in the spring of 1968, in San Antonio, drafted a proposal for a Texas Consortium to acquire Latin American archival records on microfilm. ${ }^{3}$ Interested librarians and Latin American scholars throughout Texas examined this document and the following spring the Articles of Agreement were adopted. ${ }^{4}$ Thirteen of the seventeen Texas institutions represented at the San Antonio meeting indicated a definite interest, made applications for membership, and chose an area of Mexico in which they wished to work. Three months later, at the organizational meeting of the founding members held in Austin on June 6,1969 , officers were elected and the Articles of Agreement were revised and accepted by the founding members. ${ }^{5}$

\section{Articles of Agreement}

The Texas Consortium is predicated on cooperation with other members of the Consortium and cooperation with Mexican authorities. Each member of the Consortium assumes full responsibility for working out the details for the microfilming project which it undertakes. No member institution has the right to bind any other institution in any transaction or to bind the Consortium in any manner. Microfilm acquired by each institution remains the property of that institution and not of the Consortium. Microfilm acquired by member institutions will be exchanged with other institutions under the usual interlibrary loan arrangements. The members agree to make available to all participating institutions in the Consortium copies of all finding aids produced, together with definitive indexes of their microfilm holdings as such indexes may appear. Eventually each institution in the Consortium will have a union cata$\log$ of all holdings of microfilm of Mexican Archival resources acquired under the program of the Texas Consortium.

While each institutional member takes special responsibility for a geographical or functional area of Mexico, the Articles of Agreement allows any institution to initiate a microfilm project in any area provided that the project has been cleared with all other member institutions working in the same place. The Consortium's objective is to record and make available in Texas, at a minimal cost, a maximum quantity of film of Mexican archival resources, but not to establish monopolies of special academic interests.

Any member institution wishing to withdraw from the Consortium may do so by giving notice to the Consortium three months before the beginning of the calendar year in which they will cease to participate. The present Articles of Agreement will be renegotiated at the Consortium's annual meeting in 1974. The Articles of Agreement provide for an annual meeting and for special called meetings at any time.

All Consortium members are urged, but not required, to budget a minimum of $\$ 2,000$ annually for five years for the acquisition of microfilm recording Mexican archival resources. If the present sixteen members allocate this minimum $\$ 32,000$ each year for the five-year period, $\$ 160,000$ will go into the cooperative acquisitions program. However, 
most members will be allocating much more than this minimum each year to the program. For example, Trinity University has provided $\$ 36,000$ for the first three years.

Membership in the Consortium is open to all Texas institutions who are willing to become signatory to the Articles of Agreement. At a meeting of the Texas Consortium, held in Houston on April 24, 1970, initial approval was given of a membership application from an Arizona institution, pending the amendment of the Articles of Agreement to provide for the membership of non-Texas institutions. Unfortunately, a majority of the Consortium membership has since failed to give approval for expansion of the Consortium beyond the geographical boundaries of Texas.

\section{Programs}

During the first year of the Consortium several programs were inaugurated and approximately $\$ 50,000$ was committed for microfilming. The University of Texas at Austin, with one of the nation's most outstanding Latin American collections, assumed responsibility for the federal district and for the National Archives of Mexico.

Trinity University at San Antonio negotiated a contract with the Instituto Tecnológico y de Estudios Superiores de Monterrey for 3,600 rolls of $35 \mathrm{~mm}$ positive microfilm of archival records in the state of Nuevo Leon. This plan is actually a subsidiation of Instituto Tecnológico's microfilm program which began in 1962. These records include state archives of Nuevo Leon and municipal, judicial, and ecclesiastical records of Monterrey and three other municipalities in the state of Nuevo Leon. Trinity University is investing $\$ 36,000$ during the first three years of the program. Trinity University also has a summer program in which students work in Monterrey indexing rolls of the proc- essed film; the students continue the indexing during the winter upon their return to San Antonio. Plans are being made for Instituto Tecnológico students to come to Texas for similar experience. Instituto Tecnológico is responsible for arranging the records and for filming. The librarian at Instituto Tecnológico is in charge of the project, assisted by two cameramen and two men responsible for arranging the papers for filming. The Texas State Library plans to work in partnership with Trinity and Instituto Tecnológico in filming archives in the states of Nuevo Leon and Coahuila.

St. Mary's University has completed a contract with the Universidad Autónoma de San Luis Potosí to film all archival records-state, municipal, judicial, and church-in the state of San Luis Potosí. San Luis Potosí was once the largest city between Mexico City and New Orleans, and many of these records date from the early sixteenth century. The San Luis Potosí archivist will supervise the arranging and filming of the documents. Under the agreement St. Mary's will receive the negative film and San Luis Potosí will receive a positive copy. St. Mary's has committed $\$ 5,000$ for the first year of the project.

Pan American College, Texas A. \& I., Abilene Christian College, and Southwest Texas State University are negotiating a contract with Microfilmaciones Martineau, S.A., to microfilm archives in the state of Tamaulipas. Baylor, the University of Texas at Arlington, North Texas State University, and Texas Christian University are making arrangements to film records in Michoacan. Texas Technological University, a member of the national consortium, is making contractual arrangements through that consortium for microfilming the Guadalajara archives. ${ }^{6}$

The University of Texas at El Paso has completed the filming of the Janos 
Archives in Chihuahua, eighteenth- and nineteenth-century records of the Church of Our Lady of Guadalupe in Juarez have been filmed, and a new project in Chihuahua City is being planned. The university is currently assisting in a filming project in Durango. Four students spent approximately four months arranging papers in the library division of the Museo Nacional de Anthropologia y Historia in Morelia, but this project has been discontinued, at least for the present time, because of contractual difficulties.

The University of Houston and Sam Houston State University will work as partners and be responsible for records in Puebla. The University of Houston will also film records in Mexico City.

At the December 1969 meeting of the Consortium a standard inventory format was adopted. This inventory will include place (state, municipality, church, etc.), type of archives (causas, criminales, bandos, decretos, etc.), dates, roll number, and source of other finding aids, if any. At the same time it was also agreed that each member institution would produce a roll by roll list of documents-each document will be very briefly described and the number of pages given. Each member of the Consortium will be provided with both a general holdings inventory and the roll by roll list of documents. At the present time the only finding aids which have been produced are those prepared by Trinity University for the municipal records of Cadereyta, Nuevo Leon. A complete list of the holdings of the University of Texas at Austin will be ready soon. The Instituto Tecnológico is continuing detailed indexing and has published some of their indexes to the municipal records of Monterrey. ${ }^{7}$

Institutions in the Consortium are finding their membership valuable in many ways. For example, state institutions often find it difficult to make contractual agreements with institutions in a foreign country, especially when advance payment is required, but private institutions in the Consortium will be able to act as intermediaries in these contractual arrangements. Members unable to make contacts in Mexico for microfilm projects, or unable to obtain access to certain archives, may call upon other members for assistance. A dictionary of Spanish abbreviations is being compiled at Trinity University to assist scholars in using microfilmed documents.

Thus far, most of the institutional representatives to the Consortium have been librarians and Latin American scholars rather than archivists. The result has been that the terminology and principles in the Articles of Agreement have been library- rather than archiveoriented. The Consortium would be strengthened considerably by the involvement of more archivists. For example, in the development of finding aids for the microfilm rolls, it was not until considerable energy, time, and money had been expended that it was realized that detailed library-type indexing was impractical. The arranging of archival records prior to filming probably will leave something to be desired; recommendations and supervision by experienced archivists would be invaluable here. Though it is obviously too much to expect the standards for arrangement to meet those set by the University of Texas for the Bexar Archives and those contemplated for the Nacogdoches Archives in the Texas State Archives, even limited assistance by experienced archivists would be better than the cursory arrangement that will often be given these archival records.

\section{ConcLusion}

The goals of the Texas Consortium to Microfilm Mexican Archival Resources are ambitious and probably impossible of being completely reached. But the surveying has been done, the 
foundation laid, and the structure is going up. The Texas Consortium is not like the man who inherited his father's harem and who knew what was expected of him but didn't know where to begin. The Texas Consortium not only knows what is expected of it but has already begun!

\section{REFERENCES}

1. Robert A. Houze, "The Texas Consortium for Microfilming the Mexican Archives," Texas Library Journal 45:121 (Fall 1969).

2. Office of International Librarianship, Learning Resources and Information Services, International Studies and World Affairs, State University of New York, Oyster Bay. International Conference on "Mexico on Microfilm," Final Report. Oct. 5-6, 1967. (mimeo.)

3. Microfilm Project Committee of SCOLAS. Proposal for a Consortium of Texas Academic Institutions to Acquire and Use Jointly Latin American Archival Resources on Microfilm. March 1968. (mimeo.)

4. Articles of Agreement for a Texas Consortium to Microfilm Mexican Archival Resources, Adopted March 6, 1969. (mimeo.)

5. Articles of Agreement for a Texas Consortium to Microfilm Mexican Archival Re- sources, Adopted March 6, 1969, revised June 6, 1969. (mimeo.)

6. As of January 1971 Texas Tech is the lone member of the national consortium, though five institutions are considering budgeting the required $\$ 14,000$ annually so that they may become members. When the national consortium has at least five members, the microfilming project will be initiated in Guadalajara.

7. Eugenio del Hoyo, Indice del Ramo de Causas Criminales del Archivo Municipal de Monterrey, Serie Historia, 2. Monterrey: Instituto Tecnologico, 1963, and Isreal Cavazoz Garza, Catalogo y Sintesis de los Protocolos del Archivo Municipal de Monterrey 1599-1700, Serie Historia, 4. Monterrey: Instituto Tecnologico, 1966. An index to the Salinas Victoria municipal archives is in progress. 